\title{
Evaluation of Antiurolithiatic Potentials of Hydro-Alcoholic Extract of Cucumis sativus $\mathrm{L}$.
}

\author{
Shriram Ramesh Pethakar ${ }^{1 *}$, Pramod Jayadevappa Hurkadale ${ }^{1}$, Ravindra Durdundayya Hiremath ${ }^{2}$ \\ ${ }^{1}$ Department of Pharmaceutical Biotechnology, KLE University's College of Pharmacy, Belagavi-590010, Karnataka, INDIA. \\ ${ }^{2}$ Department of Pharmaceutical Chemistry, KLE Society's College of Pharmacy,Nipani-591237, Dist. Belagavi, Karnataka, INDIA.
}

\begin{abstract}
Introduction: Cucumis sativus fruits are claimed for their antiurolithiatic activity in traditional system of medicine. Materials and Methods: Present study was undertaken to evaluate lithotryptic effect using hydro-alcoholic extract of Cucumis sativus (HCS). Ethylene glycol $(0.75 \% \mathrm{v} / \mathrm{v})$ was used to induce calculi in Wistar albino rats. Assessed various parameters like, Biochemical, Histopathological and routine urine analysis. Results: Treatment with preventive and curative doses of HCS was found to exert dose dependent antiurolithiatic action. Increased urine volume in HCS treated groups as compared to diseased group was indicative of diuretic property. Elevated calcium, phosphate and oxalate levels in diseased group animal were found to be decreased in animals treated with HCS. Increased levels of serum creatinine, BUN and uric acid were considerably brought down towards normal values in proportion to HCS doses administered. Histopathology of kidney reveals severe renal damage due toperformed crystals. Animals treated with HCS showed remarkable recovery, suggestive of prevention of nucleation and aggregation of stone forming components. Conclusion: It can be concluded that, results are supportive to claims made. The exact mechanism of antiurolithiatic effect may further needs to be studied.
\end{abstract}

Key words: Cucumis sativus, Antiurolithiatic, Ethylene glycol $(0.75 \%$ v/v), Diuretic, Cystone, Kidney stone.

\section{INTRODUCTION}

Urolithiasis is a third prevalent disorder which affects the mankind from ancient times. There are several types of kidney stones but the most common are calcium oxalate which represents the $80 \%$ of analyzed stones. ${ }^{1}$ Being a largely recurrent disease, kidney stone formation is having a relapse rate of $50 \%$ in 5-10 years which is observed to be $75 \%$ in 20 years. At present, kidney stone affects more in industrialized countries due to the change in lifestyle. Metabolic disorders such as diabetes mellitus and obesity have resulted in formation of uroliths among female population also. Age group 20 to 40 is more prone for stone formation. ${ }^{2}$ Stone formation is a complex process and involves several physicochemical events which start with crystal nucleation, super saturation, aggregation, and ending with retention within the urinary tract. ${ }^{3}$ Super saturation of urine depends upon factors such as $\mathrm{pH}$ of urine, concentration of stone forming constituents, ionic strength and complex formation of the constituents. An individual's ability to promote or prevent urolithiasis depends upon various substances present in the body which have effect on one or more of the above factors. ${ }^{4}$ No promising allopathic drugs are available in the market to dissolve or to remove the kidney stones. Treatment options such as extracorporeal shock wave lithotripsy (ESWL), percutaneous nephrostolithotomy (PCNL) and surgical procedures exist but these are expensive, recurrence is quite common and not affordable to the needy poor. ${ }^{5}$ Present days, the standard drugs used to treat urolithiasis are
Submission Date: 02-12-2016; Revision Date: 17-02-2017; Accepted Date: 27-19-2017

DOI: 10.5530/ijper.51.4s.89 Correspondence: Shriram R Pethakar, Department of Pharmaceutical Biotechnology, KLE University's College of Pharmacy, Belagavi-590010, Karnataka, INDIA.

Phone: 9860000875

E-mail: rampethkar86@ gmail.com 
not effective enough in all the patients, and in several conditions their long-term use becomes a difficulty. Also the synthetic drugs are not free from their adverse effects. Natural resources have gained attention among people due to their proven clinical efficacy and better patient compliance. In ancient literature, various drugs have been mentioned and used to treat urolithiasis under the name Pashanbheda'. Numerous plants have been studied for their antiurolithiatic potential. Tribulus terrestris, Crataeva nurvala and Dolichos biflorus showed significant antiurolithiatic activity. ${ }^{6}$ In present study an attempt has been made to explore the potent indigenous plant and emphasis on its use in prevention and treatment of urolithiasis. Cucumis sativus Linn. Fruits are reported to be useful in the treatment of renal calculus. ${ }^{7}$ However, no scientific data are available to establish the antiurolithiatic property of fruits of Cucumis sativus Linn. Hence the objective of present study is to screen and validate the antiurolithiatic activity of hydro-alcoholic extract of Cucumis sativus (HCS).

\section{MATERIALS AND METHODS}

Adult male albino rats of Wistar strain (150-200 g) were procured from Shri Venkateshwara Enterprises Bangalore. The experimental animals were housed in clean, transparent poly propylene cages maintained at $25 \pm 2^{\circ}$ C with 12/12 h light and dark cycle. The animals were acclimatized to the laboratory conditions for a week followed by random division of animals in eight groups ( $\mathrm{n}$ $=6)$. Animals were fed with standard rat chow and water ad libitum. Institutional Animal Ethical Committee (IAEC) approval (Resolution number KLECOPAEC/ Res.16 dated 20/04/2013) was obtained and care of the animals was taken as per guidelines of CPCSEA.

\section{Chemicals}

Cystone (Himalaya Health Care, India) was procured from the local market. Urocolour 10 Test Strips for routine urine analysis were procured from (SD Bio Standard Diagnostics) and ethylene glycol was obtained from Qualigen Fine Chemicals, Mumbai, India. All other chemicals and reagents used were of analytical grade.

\section{Preparation of Plant Extract}

Cucumis sativus Linn (fruits) were collected from local areas of Belgaum district in Karnataka, and were authenticated by Scientist B, Regional Medical Research Center, ICMR, Belgaum, and Karnataka, India. The herbarium was prepared and deposited in the herbaria bearing voucher specimen number RMRC-916 for selected medicinal plant. Fruits of Cucumis sativus L. were shade dried at room temperature. The dried fruits were subjected to size reduction and then sieved through sieve no.40 to get a coarse powder. Extraction was carried out by cold maceration method using ethanol (95\%) and water in ratio of (70:30) with occasional stirring for seven days. Further the extracts were filtered, combined and filtrate was concentrated under reduced pressure using rotary evaporator at $40^{\circ} \mathrm{C}$ to yield a semisolid mass which was used for further investigations.

\section{Acute Toxicity Studies}

The acute oral toxicity study was carried out as per guidelines No. 425 set by Organization for Economic Cooperation and Development (OECD). The dose $2000 \mathrm{mg} / \mathrm{kg}$ body weight was selected as a starting dose of hydro-alcoholic extract. The animals were monitored after dosing for initial $48 \mathrm{hr}$ for mortality. Also the changes in skin, fur, eyes and mucous membrane were observed along with the behavior pattern followed by specific observation for tremors and convulsions. ${ }^{8}$

\section{Experimental protocol}

Ethylene glycol $(0.75 \% \mathrm{v} / \mathrm{v})$ was used to induce urolithiasis in rats. Cystone $(750 \mathrm{mg} / \mathrm{kg})$ was used as reference standard. Experimental animals were divided into eight groups containing six animals each. Group I served as normal and received regular rat food and drinking water ad libitum. Ethylene glycol $(0.75 \% \mathrm{v} / \mathrm{v})$ in drinking water was fed to groups II served as disease for 28 days to induce kidney stone. Group III received standard antiurolithiatic drug Cystone from $15^{\text {th }}$ day served as standard curative $(750 \mathrm{mg} / \mathrm{kg}$ b.w.). Group IV received standard antiurolithiatic drug Cystone from day 1 and served as standard preventive (750 $\mathrm{mg} / \mathrm{kg}$ b.w.). Group $\mathrm{V}$ served as curative regimen (CR) and received HCS $400 \mathrm{mg} / \mathrm{kg}$ b.w from 15-28 days. Groups VII, VIII, and XI received HCS $100 \mathrm{mg} / \mathrm{kg}, 200 \mathrm{mg} / \mathrm{kg}$, and $400 \mathrm{mg} /$ $\mathrm{kg}$ body weight respectively from the 1st day till 28th day and served as preventive regimen (PR). All HCS and standard drug doses were given once daily by oral route. ${ }^{1-9}$

\section{ASSESSMENT OF ANTI-UROLITHIATIC ACTIVITY}

\section{Collection and analysis of urine}

The urine samples were collected on $14^{\text {th }}$ and $28^{\text {th }}$ day by keeping the animals in metabolic polypropylene cages for confirmation of stone formation. Animals had free accesses to drinking water during urine collection period. The volume of urine from each group of animal was measured. Further microscopy of the urine was performed at $100 \mathrm{X}$ using light electron microscope. A drop of concentrated hydrochloric acid was added to 
the collected urine and stored at $4^{0} \mathrm{C}$. The urine was analyzed for calcium, phosphate and oxalate.

\section{Change in body weight}

The change in body weight of various groups in individual animal were taken and calculated by using initial weight minus final body weight.

\section{Microscopic study of urine}

On $28^{\text {th }}$ day, the urine collected was observed under electron microscope at $40 \mathrm{X}$ for the presence of calcium oxalate and phosphate crystals. Photographs were taken using a digital camera (12 megapixels) fixed on the microscope.

\section{Serum analysis}

On the $29^{\text {th }}$ day, the animals were anesthetized with anesthetic ether and blood was collected from the retroorbital plexus under mild anesthesia. Serum was separated by centrifugation at $15,000 \mathrm{rpm}$ for $10 \mathrm{~min}$ and analyzed for calcium, uric acid, BUN and creatinine.

\section{Kidney Homogenate Analysis}

A sample of $100 \mathrm{mg}$ of the dried kidney was boiled in $10 \mathrm{ml}$ of $1 \mathrm{~N}$ hydrochloric acid for $30 \mathrm{~min}$ and homogenized. The homogenate was centrifuged at $2000 \mathrm{rpm}$ for $10 \mathrm{~min}$ and the supernatant was separated. The calcium, phosphate, uric acid, and oxalate content in the kidney homogenate were determined.

\section{Histopathology of Kidney}

The abdomen was cut open to remove both kidneys from each animal. Isolated kidneys were rinsed in an icecold physiological solution, after the extraneous tissues were removed. The right kidney was fixed in 10\% neutral buffered formalin, processed in a series of graded alcohol and xylene, embedded in paraffin wax, sectioned at $5 \mu \mathrm{m}$ and stained with hematoxylin and eosin $(\mathrm{H}$ and E) for histopathological examination. The slides were examined under a light microscope to study the architecture of the kidney and calcium oxalate deposits. ${ }^{10}$

\section{Statistical Analysis}

Results were expressed as mean \pm SEM. Differences among data were determined using one way ANOVA followed by Dunnett's multiple comparison tests (Graph pad prism). $P<0.05$ was considered to be statistically significant.

\section{RESULTS}

The preliminary phytochemical study showed the presence of various bioactive secondary metabolites such as steroids, alkaloids, flavonoids, saponins, tannins, ter- penoids and glycosides. Acute toxicity study showed no mortality, as well as any other toxic effects with a dose of $2000 \mathrm{mg} / \mathrm{kg}$ body weight. $1 / 10^{\text {th }}$ of the $\mathrm{LD}_{50}$ dose was taken as therapeutic dose for antiurolithiatic activity. Decreased $(p<0.001)$ urine excretion was observed in calculi induced (Gr. I) rats as compared with normal control (Gr. II) animals whereas a remarkable increase $(p<0.001)$ in diuresis was observed in animal treated with standard Cystone (Gr. III). There was a significant $(p<0.001)$ increase in urine volume in the animals' treated with HCS as compared with Gr. II. The increase was found to be dose dependent (Gr.VI > Gr. VII > Gr. VIII) whereas HCS curative dose (Gr. V) shows improved urine excretion as compared with Gr. II. (Table 1)

A consistent $(p<0.001)$ increase in body weight was recorded in the normal control group (Gr. I) animals, in contrary a significant decrease $(p<0.01)$ in body weight was observed in diseased group (Gr. II) from day 0 to day 28. The animals treated with standard Cystone (Gr. III and IV) showed a progressive gain in body weight both in curative and preventive dose regimen whereas there was no significant change in body weight in animals (Gr. V, VI, VII, and VIII) treated with HCS. This supports the induction of kidney stone and therapeutic efficacy of the standard drug and HCS as well. (Table 2) Urine microscopy (Figure 1) reveals the presence of characteristic shapes of the uroliths performed by administering $0.75 \% \mathrm{v} / \mathrm{v}$ ethylene glycol in rats. In nor-

\begin{tabular}{|c|c|c|}
\hline Group & Day 14 (mL) & Day $28(m L)$ \\
\hline Normal & $10.5 \pm 0.71$ & $11.33 \pm 0.21$ \\
\hline Calculi Induced & $3.83 \pm 0.31^{* * *}$ & $3.16 \pm 0.30^{\star \star *}$ \\
\hline Std. Curative & $6.83 \pm 0.30^{\# \# \#}$ & $10.17 \pm 0.31^{\# \# \#}$ \\
\hline Std. Preventive & $7.16 \pm 0.31^{\# \# \#}$ & $9.5 \pm 0.71^{\# \# \#}$ \\
\hline CS Curative & $6.67 \pm 0.49^{\# \# \#}$ & $8 \pm 0.51^{\# \# \#}$ \\
\hline CSPreventive-I & $6.16 \pm 0.31^{\#}$ & $7 \pm 0.44^{\# \# \#}$ \\
\hline CS Preventive-II & $6.5 \pm 0.71^{\#}$ & $8.33 \pm 0.33^{\# \# \#}$ \\
\hline CS Preventive-III & $6.83 \pm 0.60^{\# \#}$ & $8.83 \pm 0.31^{\# \# \#}$ \\
\hline
\end{tabular}


mal control (Gr. I) animals kidney stones were absent; while in diseased group (II) showed rectangular large $\mathrm{CaOX}$ crystals. Animals treated with standard Cystone (Gr. III and IV) showed no or almost dissolved fine crystals. HCS treated groups showed significant dose dependent activity, although finer fragments' of kidney stones were present in lower and medium dose regimen. This can be inferred as; HCS has considerable preventive as well as curative effect with dissolution of kidney stones.

In routine urine analysis, there was a marked increase in the concentration of stone forming components such as calcium, phosphate and oxalate which was decreased in the animals treated with standard drug Cyst one and HCS. HCS exhibits a dose dependent effect on lowering the concentrations of calcium, phosphates and oxalates. Thereby, inhibits formation of kidney stones. (Table 3) Serum analysis showed elevated levels of creatinine, uric acid and BUN in calculi induced animals (Gr. II) as compared to normal control animals (Gr. I). Increased levels of BUN, creatinine and uric acid causes nephritic damage and impaired kidney function. This was prevented in the animals treated with Cystone and HCS, and found to be dose dependent.

A significant increase $(p<0.001)$ in the levels of calcium, phosphate and oxalate was recorded in kidney homogenate analysis of diseased group animals (Gr. II) as compared with normal control rats (Gr. II). Treatment with Cystone and HCS showed marked decrease in the levels of these stone forming components. However, low dose of HCS (Group VI) showed poor activity as compared with high dose (Gr. VIII)

In other urine parameters as shown in Table 4, a substantial increase in $\mathrm{pH}$ (8.66) of diseased group (Gr. II) urine was recorded; on the contrary it was gradually decreased to normal value in the animals treated with standard drug Cystone and HCS (both preventive and curative). All the groups showed absence of glucose in urine. Also, other findings such as ketone bodies, urobilirubin, nitrites etc. were statistically insignificant. However, proteinuria was noted which was suggestive of severe nephritic damage in diseased group (Gr. II). A promising improvement was observed in the animals treated with both Cystone and HCS.

Histopathology of kidney showed absence of renal calculi as well as associated deformities' in normal control (Gr. I) rats. In diseased group (Gr. II), calcium oxalate crystal deposits were observed. This crystal deposition results in glomerular and peritubular congestion. Also, blood vessel congestion, epithelial desquamation and cell inflammation was noted (Figure 2). The $\mathrm{CaOx}$ depositions and related abnormalities occurred were significantly reduced on treatment with standard Cystone and HCS, where dose was crucial factor.

\begin{tabular}{|c|c|c|c|}
\hline Group & Day 0 (gm) & Day 14 (gm) & Day 28 (gm) \\
\hline Normal & $173.5 \pm 3.25$ & $190.8 \pm 2.86^{\mathrm{ns}}$ & $212 \pm 3.22^{* * *}$ \\
\hline $\begin{array}{l}\text { Calculi } \\
\text { Induced }\end{array}$ & $190.7 \pm 5.5$ & $176.5 \pm 4.74^{\mathrm{ns}}$ & $162.8 \pm 3.79^{* *}$ \\
\hline Std. Curative & $201.8 \pm 2.72$ & $184 \pm 3.43^{\text {ns }}$ & $191.5 \pm 2.32^{\mathrm{ns}}$ \\
\hline $\begin{array}{c}\text { Std. } \\
\text { Preventive }\end{array}$ & $191.7 \pm 9.71$ & $205.3 \pm 8.61$ & $\begin{array}{l}217.2 \pm \\
8.53^{\# \#}\end{array}$ \\
\hline CS Curative & $189.5 \pm 7.27$ & $179.5 \pm 7.15^{\mathrm{ns}}$ & $190.7 \pm 7.4^{\mathrm{ns}}$ \\
\hline $\begin{array}{c}\text { CS } \\
\text { Preventive I }\end{array}$ & $195.2 \pm 8.64$ & $183.8 \pm 7.44^{\mathrm{ns}}$ & $192.3 \pm 7.77^{\mathrm{ns}}$ \\
\hline $\begin{array}{c}\text { CS } \\
\text { Preventive II }\end{array}$ & $189.5 \pm 7.27$ & $179.5 \pm 7.15$ & $185.8 \pm 9.52^{\mathrm{ns}}$ \\
\hline $\begin{array}{c}\text { CS } \\
\text { Preventive III }\end{array}$ & $195.2 \pm 5.74$ & $182 \pm 7.64$ & $189.5 \pm 5.35^{\mathrm{ns}}$ \\
\hline $\begin{array}{l}\text { \# Compared with } \\
{ }^{*} \text { Compared with } \\
*=\mathrm{P}<0.05, * *= \\
\text { induced } \\
\text { ns }- \text { Non significa }\end{array}$ & $\begin{array}{l}\text { Iculi induced } \\
\text { yo } \\
0.01, * * *=P\end{array}$ & $\begin{array}{l}\text { - Compared with d } \\
1 \text { :Significant as co }\end{array}$ & npared with calculi \\
\hline
\end{tabular}

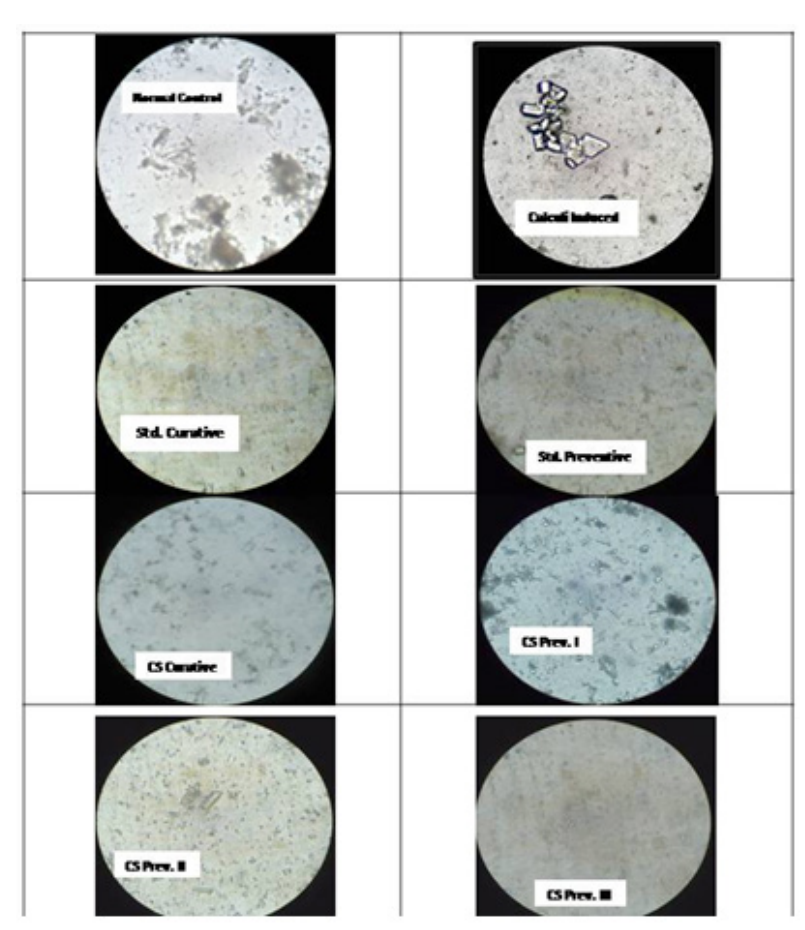

Figure 1: Urine Microscopy 


\begin{tabular}{|c|c|c|c|c|c|c|c|c|c|}
\hline Param & eters & Group I & Group II & Group III & Group IV & Group V & Group VI & Group VII & Group VIII \\
\hline Nor & & normal & Calculi & Std. & Std. & CS & CS & CS & CS \\
\hline & Calcium & $\begin{array}{l}4.6 \pm \\
0.12\end{array}$ & $\begin{array}{l}8.25^{* * * a} \\
\pm 0.50\end{array}$ & $\begin{array}{c}4.91 \pm \\
0.20\end{array}$ & $\begin{array}{c}5.26 \\
\pm 0.09\end{array}$ & $\begin{array}{c}5.46 \\
\pm 0.12\end{array}$ & $\begin{array}{c}6.07 \\
\pm 0.15\end{array}$ & $\begin{array}{c}5.9 \\
\pm 0.13\end{array}$ & $\begin{array}{l}5.5^{n+m b} \\
\pm 0.13\end{array}$ \\
\hline Urine & Phosphate & $\begin{array}{l}145.0 \\
\pm 1.6\end{array}$ & $\begin{array}{c}348.2^{* * \star a} \\
\pm 1.9\end{array}$ & $\begin{array}{c}186 \\
\pm 2.06\end{array}$ & $\begin{array}{r}187 \\
\pm 3.4\end{array}$ & $\begin{array}{r}202.8 \\
\pm 0.90\end{array}$ & $\begin{array}{r}219 \\
\pm 5.1\end{array}$ & $\begin{array}{r}206.2 \\
\pm 1.3\end{array}$ & $\begin{array}{c}190.3^{* * b} \\
\pm 3.9\end{array}$ \\
\hline & Oxalate & $\begin{array}{l}1.8 \\
\pm \\
0.05\end{array}$ & $\begin{array}{l}4.96^{*+* a} \\
\pm 0.09\end{array}$ & $\begin{array}{c}2.06 \\
\pm 0.07\end{array}$ & $\begin{array}{c}2.06 \\
\pm 0.11\end{array}$ & $\begin{array}{c}2.56 \\
\pm 0.05\end{array}$ & $\begin{array}{c}2.65 \\
\pm 0.05\end{array}$ & $\begin{array}{c}2.18 \\
\pm 0.11\end{array}$ & $\begin{array}{l}2.31^{* * * b} \\
\pm 0.1\end{array}$ \\
\hline & BUN & $\begin{array}{l}24.17 \\
\pm 0.31\end{array}$ & $\begin{array}{c}40.17^{* * a} a \\
\pm 0.40\end{array}$ & $\begin{array}{c}26.8 \\
\pm 0.40\end{array}$ & $\begin{array}{l}25.83 \\
\pm 0.70\end{array}$ & $\begin{array}{l}29.5^{* * * b} b \\
\pm 0.76\end{array}$ & $\begin{array}{c}34.33^{\text {ns b }} \\
\pm 0.61\end{array}$ & $\begin{array}{l}29.6 \\
\pm 1.1\end{array}$ & $\begin{array}{l}26.2^{\ldots * * b} \mathrm{~b} \\
\pm 0.54\end{array}$ \\
\hline Serum & Creatinine & $\begin{array}{c}0.56 \pm \\
0.01\end{array}$ & $\begin{array}{l}0.90^{+* * a} \\
\pm 0.01\end{array}$ & $\begin{array}{c}0.58 \\
\pm 0.01\end{array}$ & $\begin{array}{c}0.57 \\
\pm 0.013\end{array}$ & $\begin{array}{l}0.61^{+* * b b} \\
\pm 0.01\end{array}$ & $\begin{array}{c}0.77 \\
\pm 0.02\end{array}$ & $\begin{array}{c}0.66 \\
\pm 0.02\end{array}$ & $\begin{array}{l}0.61^{* \mathrm{~b}} \\
\pm 0.02\end{array}$ \\
\hline & Uric acid & $\begin{array}{c}1.78 \\
\pm 0.06\end{array}$ & $\begin{array}{l}5.96^{* * * a} \\
\pm 0.08\end{array}$ & $\begin{array}{r}1.85 \\
\pm 0.04\end{array}$ & $\begin{array}{c}2.03 \\
\pm 0.08\end{array}$ & $\begin{array}{c}2^{* * * b} \pm \\
0.06\end{array}$ & $\begin{array}{l}3.58^{*} \\
\pm 0.14\end{array}$ & $\begin{array}{c}2.53 \pm \\
0.14\end{array}$ & $\begin{array}{l}2.15^{* * * b} \\
\pm 0.07\end{array}$ \\
\hline & Calcium & $\begin{array}{c}5.48 \\
\pm 0.18\end{array}$ & $\begin{array}{l}11.6^{* * * a} \\
\pm 0.24\end{array}$ & $\begin{array}{c}6.45 \\
\pm 0.08\end{array}$ & $\begin{array}{c}6.48 \pm \\
0.10\end{array}$ & $\begin{array}{l}6.83 \\
\pm 0.1\end{array}$ & $\begin{array}{l}7.1^{* \mathrm{~b}} \\
\pm 0.1\end{array}$ & $\begin{array}{l}6.4^{* * b} \\
\pm 0.19\end{array}$ & $\begin{array}{l}6.63^{* * b} \\
\pm 0.17\end{array}$ \\
\hline $\begin{array}{c}\text { Kidney } \\
\text { Homogenate }\end{array}$ & Phosphate & $\begin{array}{r}1.50 \\
\pm 0.1\end{array}$ & $\begin{array}{l}5.51^{* * * a} \\
\pm 0.16\end{array}$ & 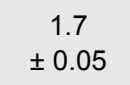 & $\begin{array}{c}1.83 \\
\pm 0.02\end{array}$ & $\begin{array}{c}2.06 \\
\pm 0.06\end{array}$ & $\begin{array}{c}2.50 \\
\pm 0.22\end{array}$ & $\begin{array}{c}2.06 \\
\pm 0.07\end{array}$ & $\begin{array}{l}1.86^{* * * \mathrm{~b}} \\
\pm 0.07\end{array}$ \\
\hline & Oxalate & $\begin{array}{c}2.73 \\
\pm 0.09\end{array}$ & $\begin{array}{l}7.93^{\ldots+* a} \\
\pm 0.26\end{array}$ & $\begin{array}{c}3.48 \\
\pm 0.08\end{array}$ & $\begin{array}{l}3.4 \pm \\
0.10\end{array}$ & $\begin{array}{c}3.73 \\
\pm 0.12\end{array}$ & $\begin{array}{l}3.9 \\
\pm 0.09\end{array}$ & $\begin{array}{c}3.81 \pm \\
0.11\end{array}$ & $\begin{array}{l}3.78^{+* * b} \\
\pm 0.12\end{array}$ \\
\hline
\end{tabular}

$*=\mathrm{P}<0.05, * *=\mathrm{P}<0.01, * * *=\mathrm{P}<0.001$ :Significant as compared with calculi induced $\mathrm{ns}=$ Not statistically significant $\mathrm{a}=$ Compared with normal group, $\quad \mathrm{b}=$ compared with calculi induced group

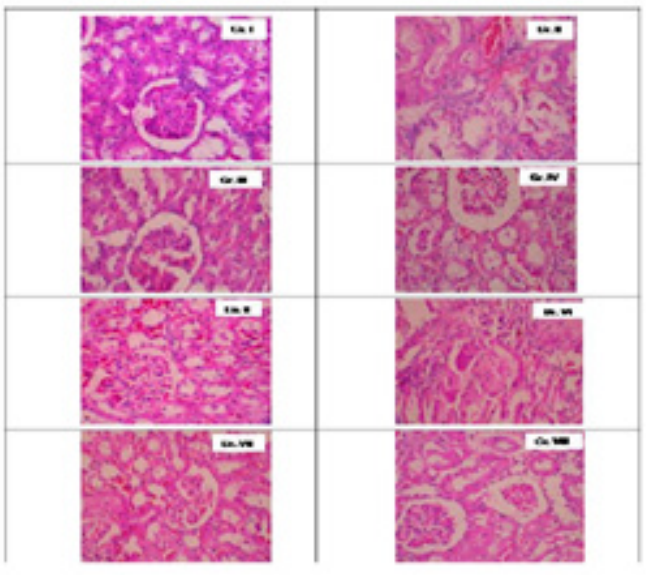

Figure 2: Histopathology of kidney.

\section{DISCUSSION}

Induction of uroliths can be achieved by using various stone forming agents such as ethylene glycol, ammonium oxalate, glycolic acid; sodium oxalate etc. ${ }^{3}$ In the present study, $0.75 \% \mathrm{v} / \mathrm{v}$ ethylene glycol was administered orally for 14 days and till $28^{\text {th }}$ day to induce urolithiasis in the curative and preventive study group animals respectively. Ethylene glycol thus administered was metabolized into glycolic acid, glycooxalic acid, oxalic acid and glycolaldehyde; which results in hyperoxalurea; a major risk factor in urolithiasis. ${ }^{11}$

Remarkable decrease in body weight confirms the induction of calculi in diseased group than normal control animals. The progressive increase in urine output in the animals treated with HCS indicates promising diuretic activity which results in minimizing the concentration of stone forming components thereby reducing the chances of precipitation and formation of uroliths. ${ }^{10}$

The characteristic crystals were observed in microscopic examination of urine. Enhanced substrate availability by ethylene glycol, facilitates activation of glycolate oxidase; an oxalate synthesizing enzyme, which results in increased oxalate production. ${ }^{12}$ Also, increased level of stone forming components such as calcium, phosphates and uric acid forms a conducive environment for nephrolithiasis. A significant difference was observed in the size and quantum of crystals in the groups treated with HCS with different dosage levels. In group V (Std. Curative) and VIII (high dose Preventive) the amount 
Table 4:Effect of hydro-alcoholic extracts of Cucumis sativus on urine parameters.

\begin{tabular}{|c|c|c|c|c|c|c|c|c|}
\hline & Group I & Group II & Group III & Group IV & Group V & Group VI & Group VII & Group VIII \\
\hline & Normal & $\begin{array}{l}\text { Disease } \\
\text { (Calculi } \\
\text { Induced) }\end{array}$ & $\begin{array}{l}\text { Standard } \\
\text { Curative } \\
\text { (Cystone) }\end{array}$ & $\begin{array}{l}\text { Standard } \\
\text { Preventive } \\
\text { (Cystone) }\end{array}$ & $\begin{array}{l}\text { C. sativus } \\
\text { Curative }\end{array}$ & $\begin{array}{l}\text { C. sativus } \\
\text { Preventive I }\end{array}$ & $\begin{array}{c}\text { C. sativus } \\
\text { Preventive II }\end{array}$ & $\begin{array}{c}\text { C. sativus } \\
\text { Preventive II }\end{array}$ \\
\hline $\begin{array}{c}\text { Blood } \\
(\mathrm{RBC} / \mu \mathrm{L})\end{array}$ & $A B$ & $150 \pm 44.7$ & $1.66 \pm 1.66$ & $A B$ & $3.33 \pm 2.1$ & $25 \pm 11.18$ & $6.66 \pm 2.1$ & $1.66 \pm 1.66$ \\
\hline Bilirubin & $A B$ & $0.83 \pm 0.1$ & $0.17 \pm 0.10$ & $0.17 \pm 0.10$ & $0.17 \pm 0.10$ & $0.66 \pm 0.21$ & $0.33 \pm 0.16$ & $0.25 \pm 0.17$ \\
\hline Urobilinogen & $0.25 \pm 0.15$ & $1.0 \pm 0$ & $0.4 \pm 0.18$ & $0.7 \pm 0.18$ & $0.4 \pm 0.18$ & $0.7 \pm 18$ & $0.55 \pm 0.20$ & $0.55 \pm 0.20$ \\
\hline Ketone & $1.66 \pm 1.05$ & $22.5 \pm 8.7$ & $1.66 \pm 1.66$ & $0.83 \pm 0.83$ & $0.83 \pm 0.83^{*}$ & $10 \pm 8.06$ & $4.16 \pm 2.0$ & $2.5 \pm 1.7$ \\
\hline Protein & $A B$ & $20 \pm 4.47$ & $5 \pm 5$ & $3.33 \pm 2.1$ & $3.33 \pm 2.1$ & $10 \pm 4.47$ & $6.66 \pm 4.94$ & $5 \pm 5$ \\
\hline Nitrite & $A B$ & $0.91 \pm 0.08$ & $0.75 \pm 0.17$ & $0.75 \pm 0.17$ & $0.41 \pm 0.20$ & $0.41 \pm 0.15$ & $0.66 \pm 0.16$ & $0.75 \pm 0.17$ \\
\hline Glucose & $A B$ & $A B$ & $A B$ & $A B$ & $A B$ & $A B$ & $A B$ & $A B$ \\
\hline $\mathrm{pH}$ & $6.08 \pm 0.23$ & $8.66 \pm 0.21$ & $6.5 \pm 0.18$ & $6.75 \pm 0.17$ & $6.83 \pm 0.10$ & $7.41 \pm 0.23$ & $6.58 \pm 0.23$ & $6.41 \pm 0.20$ \\
\hline $\begin{array}{l}\text { Specific } \\
\text { Gravity }\end{array}$ & $\begin{array}{l}1.002 \pm \\
0.001\end{array}$ & $\begin{array}{l}1.024 \pm \\
0.0008\end{array}$ & $\begin{array}{c}1.002 \pm \\
0.001\end{array}$ & $\begin{array}{c}1.005 \pm \\
0.003\end{array}$ & $\begin{array}{c}1.005 \pm \\
0.003\end{array}$ & $\begin{array}{c}1.018 \pm \\
0.003\end{array}$ & $\begin{array}{l}1.01 \pm \\
0.0048\end{array}$ & $\begin{array}{l}1.004 \pm \\
0.0032\end{array}$ \\
\hline $\begin{array}{l}\text { Leucocytes } \\
\text { (WBC/ } / \mu \mathrm{L})\end{array}$ & $A B$ & $41.67 \pm 10.54$ & $8.33 \pm 5.27$ & $8.33 \pm 5.27$ & $12.5 \pm 12.5$ & $\begin{array}{c}29.17 \pm \\
15.02\end{array}$ & $\begin{array}{c}16.67 \pm \\
12.36\end{array}$ & $8.33 \pm 5.27$ \\
\hline \multicolumn{9}{|c|}{ *Blood $(\mathrm{RBC} / \mu \mathrm{L})+10,++50,+++250^{\circ}$} \\
\hline
\end{tabular}

of $\mathrm{CaOX}$ crystals were almost absent or dissolved or inhibited the aggregation to a greater extent.

Urine flow gets obstructed due to the stones in the urinary system which results in decreased glomerular filtration rate. Reduced GFR, leads to accumulation of nitrogenous waste products in blood causing severe renal damage. This was supported by the observance of proteinurea as shown in Table 4. Increase in urinary $\mathrm{pH}$ is the major factor in process of stone formation. In normal control group $\mathrm{pH}$ of urine was 6.08 whereas increase $\mathrm{pH}$ (8.66) in diseased group animals was observed which results in formation of renal calculi. Presence of RBC's and blood was due to severe nephritic injury caused by the calculi formed which was highest in diseased group animals. Animals treated with HCS showed decrease in $\mathrm{pH}$ proportionate to the dose administered.

Calcium, phosphate and oxalate have a crucial role in litho-genesis. ${ }^{13}$ In calculi induced experimental animals, urinary excretion and renal accumulation of these components was significantly increased. This may be attributed due to defective tubular reabsorption. ${ }^{14}$ Animals treated with HCS [Both curative (Gr. V) and preventive (Gr. VI < VII < VIII)] showed recovery in GFR which is suggestive of potential clinical efficacy in the management of kidney stone

Serum parameters reveal remarkable elevation in the levels of BUN, creatinine and uric acid, depict glomerular and tubular injury. Increased level of uric acid results in absorption of glutamic acid and other organic constituents, which is a favorable condition for $\mathrm{CaOX}$ crystal aggregation. Animals treated with HCS shows significant dose dependent recovery evident by decreased levels of BUN, creatinine and uric acid. ${ }^{15}$

Deposition of varied shapes of renal calculi was evident from the histopathology of kidney. The increased level of calcium oxalate was believed to be the causative factor in interstitial inflammation. HCS treated animals exhibits lesser amount and sizes of stones, thereby protecting from renal injury.

\section{CONCLUSION}

It can be inferred from the observations made, that HCS have the potential in preventing and curing the kidney 
stones. The effect was more promising in the highest dose of HCS. The effect may be attributed to the lowering the concentration of stone forming components, diuretic effect and inhibiting the process of lithogenesis, thereby protecting from nephritic damage. The results interpreted are in accordance and supportive to the claims made in traditional system of medicine.

\section{ACKNOWLEDGMENT}

The authors are thankful to Deputy Director, Dr. Prabhakar Kore Basic Science Research Centre, Belagavi, India, for providing facilities to carry out this research work. The authors are grateful to Scientists, RMRC, Belgaum, for authenticating the plant material.

\section{CONFLICT OF INTEREST}

Authors do not have any conflict of interest.

\section{ABBREVIATION USED}

CS: Cucumis sativus: HCS: Hydro-alcoholic extract of Cucumis sativus; \% v/v: Percentage volume by volume; ESWL: Extracorporeal shock wave lithotripsy; PCNL: Percutaneous nephrostolithotomy; OECD: Organization for Economic Cooperation and Development; g: Gram; b.w.: Body Weight; PR: Preventive regimen; H and E: Hematoxylin and eosin; CaOX: Calcium Oxalate; GFR: Glomerular filtration rate; BUN: Blood Urea Nitrogen.

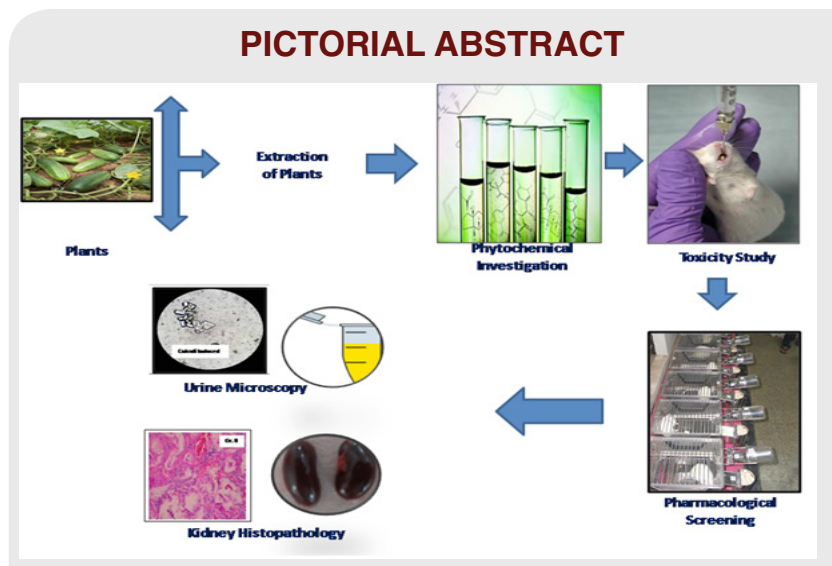

\section{REFERENCES}

1. Atmani F, Slimani Y, Mimouni M, Aziz M, Hacht B, Ziyyat A. Effect of aqueous extract from Herniaria hirsuta L. on experimentally nephrolithiasic rats. J Ethnopharmacol. 2004;95(1):87-93.

2. Chen YT. Urolithiasis update: Evaluation and management. Urol Sci. 2012;23(1):5-8.

3. Khan SR. Interactions between stone-forming calcific crystals and macromolecules. Urol Int. 1997;59(2):59-71.

4. Sasikala V, Radha SR, Vijayakumari B. In vitro evaluation of Rotula aquatica Lour. for antiurolithiatic activity. J Pharm Res, 2013;6(3):378-82.

5. Prasad K, Sujatha D, Bharathi K. Herbal drugs in urolithiasis - a review. Pharmacognosy Res. 2007;1(1):175-9.

6. Tiwari A, Soni V, Londhe V, Bhandarkar A, Bandawane D, Nipate S. An overview on potent indigenous herbs for urinary tract infirmity: Urolithiasis. Asian J Pharm Clin Res. 2012;5(1):7-12.

7. Indian Medicinal Plants, Arya Vaidya Sala, Orient Longman. 1994;2:231-4.

8. OECD guidelines No. 425 for the testing of chemicals. Received draft adopted from $3^{\text {rd }}$ October 2008.

9. Gadge NB, Jalalpure SS. Curative treatment with extracts of Bombax ceiba Fruit Reduces Risk of Calcium Oxalate Urolithiasis in Rats. Pharm Biol. 2012;50(3):310-17.

10. Shah J, Patel B, Patel S, Patel R. Antiurolithiatic and antioxidant activity of Hordeum vulgare seeds on ethylene glycol-induced urolithiasis in rats. Indian J Pharmacol. 2012;44(6):672-7

11. Sumathi R, Jayanthi S, Kalpanadevi V, Varalakshmi P. Effect of DL $\alpha$-Lipoic acid on tissue lipid peroxidation and antioxidant systems in normal and glycollate treated rats. Pharmacological Research. 1993;27(4):309-318.

12. Schladt L, Ivens I, Karbe E, Rühl-Fehlert C, Bomhard E. Subacute oral toxicity of tetraethylene glycol and ethylene glycoladministered to Wistar rats. Experimental and Toxicologic Pathology. 1998;50(3):257-65.

13. Makasana A, Ranpariya V, Desai D, Mendpara J, Parekh V. Evaluation for the anti-urolithiatic activity of Launaea procumbens against ethylene glycolinduced renal calculi in rats. Toxicol Reports. 2014;1:46-52.

14. Nayeem K, Gupta D, Nayana H, Joshi RK. Antiurolithiatic potential of the fruit extracts of Carica papaya on ethylene glycol induced urolithiatic rats. Journal of Pharmacy Research. 2010;3(11):2772-5.

15. Ashok P, Koti BC, Vishwanathswamy AHM. Antiurolithiatic and antioxidant activity of Mimusops elengi on ethylene glycol-induced urolithiasis in rats. Indian J Pharmacol. 2010;42(6):380-3.

\section{About Authors}

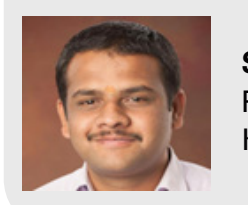

Shriram Ramesh Pethakar: Presently working as Ph.D. research scholar under the guidance of Prof Pramod J Hurkadale at department of biotechnology, KLE University College of Pharmacy, Belagavi, Karnataka. He published 04 research papers and presented 04 posters at national conferences. 


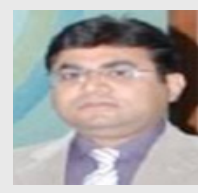

Pramod J Hurkadale: Presently working as Professor, Department of Pharmaceutical Biotechnology KLE University College of Pharmacy, Belagavi, Karnataka. His areas of research include isolation/ characterization of active principles from medicinal plants and their pharmacological screening and training research students in Biotechnology, Pharmacognosy and Phytochemistry aspects and techniques. He has 31 of research papers and 44 posters presented in national and international workshops and conferences and written 02 books. Gave more than 18 invited talks. He is having total 16 years of teaching experience with 11 years of Research experience. He is guiding $M$. Pharmacy students and PhD Research Scholar.

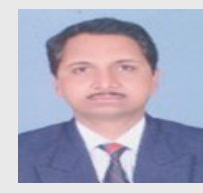

Ravindra D Hiremath: Working as Associate Professor, Department of Pharmaceutical Chemistry, KLE Society's College of Pharmacy, Nippani, Karnataka. He is having 17 years of teaching and 4 years of research experience. He is teaching under graduate as well as post graduate students. He has published 09 scientific research papers and presented 10 at national conferences. He is actively involved in the research activity.

Cite this article: Pethakar SR, Hurkadale PJ, Hiremath RD. Evaluation of Antiurolithiatic Potentials of Hydro-Alcoholic Extract of Cucumis sativus L. Indian J of Pharmaceutical Education and Research. 2017;51(4S):S607-S14. 